Article

\title{
Can a Short Food Supply Chain Create Sustainable Benefits for Small Farmers in Developing Countries? An Exploratory Study of Vietnam
}

\author{
Thi Nga Bui ${ }^{1, *}$, An Ha Nguyen ${ }^{2}$, Thi Thu Huong Le ${ }^{1}$ (), Van Phuong Nguyen ${ }^{1}$, Thi Thanh Hao Le ${ }^{1}$, Thi Thanh \\ Huyen Tran ${ }^{1}$, Ngoc Mai Nguyen ${ }^{1}$, Thi Kim Oanh Le ${ }^{1}$, Thi Kim Oanh Nguyen ${ }^{1}$, Thi Thu Trang Nguyen ${ }^{1}$, Hong \\ Van Dao ${ }^{1}$, Thi Ngoc Thuy Doan ${ }^{1}$, Thi Hang Nga Vu ${ }^{1}{ }^{1}$, Viet Hung Bui ${ }^{2}$, Huu Cuong Hoa ${ }^{2}$ and Philippe Lebailly ${ }^{3}$
}

1 Faculty of Accounting and Business Management, Vietnam National University of Agriculture, Hanoi 100000, Vietnam; thuhuonglt.qtkd@gmail.com (T.T.H.L.); phuonglangvan@gmail.com (V.P.N.);

haotron_ke@yahoo.com (T.T.H.L.); huyenqt.hua@gmail.com (T.T.H.T.); mainn410@gmail.com (N.M.N.); ltkoanh2010@gmail.com (T.K.O.L.); kimoanh.vcu@gmail.com (T.K.O.N.); nt2trang.kt@gmail.com (T.T.T.N.); dhvan24@gmail.com (H.V.D.); doanngocthuy89@gmail.com (T.N.T.D.); vunga0304@gmail.com (T.H.N.V.)

2 Institute for European Studies-Vietnam Academy of Social Sciences, Hanoi 100000, Vietnam; anhad4@yahoo.com (A.H.N.); hungbui_eu@yahoo.com (V.H.B.); cuonghh@hht.edu.vn (H.C.H.)

3 Economics \& Rural Development, Gembloux Agro-Bio Tech, University of Liege, 5030 Gembloux, Belgium; philippe.lebailly@uliege.be

* Correspondence: hieu0306@gmail.com; Tel.: +84(0)-918839181

\section{check for} updates

Citation: Bui, T.N.; Nguyen, A.H.; Le, T.T.H.; Nguyen, V.P.; Le, T.T.H.; Tran, T.T.H.; Nguyen, N.M.; Le, T.K.O.; Nguyen, T.K.O.; Nguyen, T.T.T.; et al. Can a Short Food Supply Chain Create Sustainable Benefits for Small Farmers in Developing Countries? An Exploratory Study of Vietnam. Sustainability 2021, 13, 2443 https://doi.org/10.3390/su13052443

Academic Editor: Luigi Roselli

Received: 29 December 2020

Accepted: 20 February 2021

Published: 24 February 2021

Publisher's Note: MDPI stays neutral with regard to jurisdictional claims in published maps and institutional affiliations.

Copyright: (c) 2021 by the authors. Licensee MDPI, Basel, Switzerland. This article is an open access article distributed under the terms and conditions of the Creative Commons Attribution (CC BY) license (https:// creativecommons.org/licenses/by/ $4.0 /)$.

\begin{abstract}
A number of studies have indicated that short food supply chains could create economic, social, and environmental benefits, but most of those chains were implemented in developed countries. This research aims to find out the characteristics of short food supply chains and their benefits to small farmers in Vietnam, which is a developing country, based on the survey results from 338 small farmers in the third quarter of 2020, with the support of Stata 14 software. The results showed that the short food supply chains in the survey sample in Vietnam were characterized by two main actors: small farmers and distributors. Farmers could sell products flexibly at the local market. There was some initial evidence to prove that these chains helped to stabilize the input, output price, and revenue; formulated sustainable income; and increased the satisfaction and confidence of farmers. They eliminated gender discrimination in rural areas and improved livelihood for ethnic minorities. These chains also enhanced the mindset on green, organic, and clean production of farmers, which in turn created environmental benefits. COVID-19 has posed a negative impact on the income of farmers and made them change their production and sales method. Therefore, the research could suggest some policies to sustainably develop the short food supply chains in Vietnam in the future.
\end{abstract}

Keywords: sustainable development; short food supply chains; impact of Covid-19; developing countries; small farmers; local market; Vietnam

\section{Introduction}

Short food supply chains (SFSCs) are alternative food markets that are characterized by few (or none) intermediaries between producers and consumers [1], or the production and distribution take place in a certain geographical area, also considered as a local market [2]. The SFSCs aims to provide consumers with products that contain the characteristics of local identity, nature, health, and trustworthiness [3].

There are three main types of SFSCs, namely: direct chains, which are the chains where farmers make products and sell directly to consumers; short-distance chains are the chains in which farmers make products and sell them within geographical proximity, usually around the production sites; and extended chains are the chains that may have geographical coverage, where farmers can sell products to consumers through local specialty stores or organic product stores $[1,4]$. 
While conventional supply chains (long chains), especially global chains, could exploit the competitive advantage and economies of scales, contribute to the development of industrial technology, satisfy the increasing demand and supply sources, improve information availability and plentiful venture capital [5,6], SFSCs can complement long chains to diversify the sources of food supply [7]. There was some evidence that SFSCs had a higher multiplier effect on local economies, especially in rural areas, than the long chains did. Farmers who joined SFSCs were more likely to diversify their products. In some cases, farms who joined SFSCs had a higher workforce $[8,9]$ and gained a higher income per asset and hour-but those results were very heterogeneous among farms, got more adequate prices and higher value-added [10], and reduced economic uncertainties [11] compared with long chains.

In recent years, many researchers have studied SFSCs and pointed out that these chains contributed to sustainable development in economic, social, and environmental terms [12-15]. The SFSCs were considered to bring economic benefits to farmers, consumers, and local communities. Scientists believed that the SFSCs created jobs and increased income in rural areas, enhanced job satisfaction and improved the capacity of local communities, as well as raised consumer beliefs in the agricultural system, minimized waste, and avoided migration from rural areas to the city centers [16]. It helped to increase value-added and was a driver of rural economic regeneration [17], designed a new economic space, and changed the decline in rural services and agricultural production infrastructure $[1,18,19]$. Local trade, demand for local services, and labor markets would increase with exponential effects thanks to the reduction of intermediaries and linkages in the supply chain. Job opportunities were created directly from production and sales activities such as planting, picking, packaging, selling, etc., or indirectly through delivery services from material suppliers to retail stores. The SFSCs also brought opportunities for the development of the tourism industry (especially for local brands and specialties) and other service industries in local communities, thereby positively contributed to the local economy [20].

Some researchers argued that SFSCs contributed to the increase in income for producers by giving them chances to sell at a higher price, receive a larger share of the profits due to the elimination of middlemen, and diversify and increase the value of their products [20-22]. Others indicated that short food chain development through on-farm marketing and sales was stable, and that it reduced marketing costs due to brand commitment, good product quality, and accessibility [23]. Other studies presented that effective supply chain management could contribute to the increase of the sustainable competitive advantage for organizations [24-27]. SFSC management helped to enhance the efficiency of the actors involved in the chain through the effective use of resources and the development of internal and external linkages to create the coherent coordination, thus, increasing competition between producers across the chain [24,28-33]. Effective linkages in the SFSCs contributed to improving the performance of enterprises and chain actors [34-38] and might provide a sustainable potential competitive advantage [10,39]. Informationbased linkage, if managed effectively, could increase the performance of customers and suppliers [7,40-42], and this would, in turn, improve the efficiency of chain actors [43-49].

From the social perspective, studies showed that the SFSCs contributed to the increase of social interaction, trust, and social cohesion, built a sense of community and impulse relationships between production and consumption, as well as enhanced the knowledge which leads to behavioral changes [21]. It is believed that trust had been built up via the direct interaction between producers and consumers at agricultural markets in the United Kingdom [23]. The trust was not only related to the product itself, but also increased the consumer beliefs in the farmer's responsibility and safe production practices [50]. Another study pointed out that social benefits were one of the main factors that enhanced producers and consumers to participate in the agricultural markets [51]. The SFSCs could renew the relationship between producers by separating the political relationships and enhancing the coherence of sales [52]. Some other scientists found a change in behavior 
among participants in a Community-Supported Agriculture model, which was the change of the cooking and eating habits, mainly through consuming more local, seasonal, and healthy foods $[53,54]$.

In terms of sustainable environmental development, scientists believed that the SFSCs represented in the local food model brought benefits to the environment by reducing greenhouse gas emissions [55]. Other researchers considered the SFSCs as a way of biodiversity improvement [56]. Although there was evidence in previous studies that SFSCs had a positive effect on the environment (reducing carbon footprint), it was still uncertain and needed more research $[57,58]$.

Small farmers are characterized by small production volumes due to limited production resources, low levels of investment, and limited access to knowledge of advanced technologies and practices [59]. They play an important role in the socio-economic development and political stability of rural areas because they create products to ensure food security, nutrition, and health of many poor people [60]. There are some opportunities for the production of small farmers in developing countries. A rapid rise in population could create an increasing demand on the volumes of food products in general and products from small farmers, in particular [61]. In addition, governments also recognized the role of local food and encouraged consumers to purchase products from small farmers [7]. Market liberalization around the world with the 4.0 technology development also generates opportunities for small farmers to enlarge their market.

However, they might encounter many difficulties, including high levels of input price and production risks; uncertainty output market; limited access to new technologies and market information; inadequate infrastructure, high costs of storage and transportation, and non-competitive markets [59]. In addition, due to poor access to markets and lack of agricultural market information, there was some evidence that traders benefited more while farmers sold their products $[62,63]$.

In the horticultural sector, there are many kinds of products, such as tree fruits and soft fruits to field vegetables and protected crops. They are one of the most important food groups and use mainly for human food consumption. A small proportion of horticultural products are used in pharmaceuticals; fibers and fuels; or for non-human uses such as animal feeds and industrial applications [64]. Horticultural supply chains comprise all activities from input supply such as seeds, fertilizer, chemicals, etc., through production, post-harvest operations, distribution, and retail. These chains relate to a fragmented loose chain with weak links among actors [65]. In the horticultural sector, most of the farms are small, and its markets are almost imperfect. Integrating small horticultural farmers into a high value-added supply chain could help them develop sustainably [66].

Vietnam is predominantly an exporter of horticultural products. The horticultural sector in Vietnam was characterized by a diversified fruit and vegetable small farm with a cultivated land of around 0.5 hectares. In Vietnam, horticultural supply chains, producers, collectors, wholesalers, retailers, and export organizations are the main actors who could take one or more functions along the chain. The horticulture value chains in Vietnam are dysfunctional and need more change [67].

With a population of 97.3 million in 2020 [68] and the increasing demand for greater diversity and quality in food products from the fast-growing middle-class consumers [67], there is a large domestic market opportunity for horticultural products in Vietnam. However, the majority of the people in Vietnam are buying horticultural products from unorganized local sources like wet markets and street vendors. A price information system is not reliable and the distribution of the added value of the chain is unfavorable to farmers [67]. Therefore, developing SFSCs, especially horticultural chains, could contribute to sustainable development not only for small farmers, but also for consumers and local communities in Vietnam in the future.

A lot of studies showed that SFSCs created benefits for the whole societies or specific farmers $[59,60]$, but most of the researches were carried out in developed countries like Scotland, England, Wales, Ireland, France, Greece, Finland, Poland, Germany, Italy, etc. [69]. 
How do SFSCs in developing countries work? Can small farmers in developing countries get benefits from SFSCs? To understand this situation, this research has been implemented in Vietnam, a developing country, as an exploratory study to find out characteristics of SFSCs and their benefits to small farmers, and suggest some polices to improve the benefits for small farmers.

\section{Materials and Methods}

The research focuses mainly on the qualitative features of SFSCs for selected small farmers, with some quantitative information, in particular, the economic data of the farmer's production. A structured questionnaire set was designed to interview farmersthe major and most important actor in the SFSCs. Firstly, a semi-structured interview was used to collect qualitative data and information [70] to define the SFSCs, describe the characteristics of the chain actors, flow of information, flow of products, and supporting system. The specific research areas were designed (which were region, province, district, communes, and villages), then a sample of small farmers was chosen. The results of this step were to comprehend the general situation of the study sites, understand the geography, the habits, working hours, methods of transportation used in the study sites, and the difficulties and challenges before the survey was carried out. A pre-test of the questionnaire was also conducted in this interview to develop the formal version of the questionnaire. Secondly, a structured interview with a standard questionnaire was used to collect qualitative and quantitative data for the analysis [71]. The questionnaire included 63 questions, presented in six sections: General information of small farmers (6 questions); Characteristics of farm production (16 questions); Market and sales (11 questions); Participation of farm in the SFSCs (14 questions); Risks and impact of coronavirus (COVID-19) pandemic (9 questions); and Potential and demand for support to develop SFSCs sustainably (7 questions).

The next method to collect data was through informal conversational interviews. This method is very flexible and appropriate for exploring a broad field related to farming [72] and gain insight into problems in the target study villages. In-depth interviews provide qualitative and quantitative information on the chain and are particularly useful for different participants in the chain to understand their complementary relationships. Observation is used to obtain qualitative and quantitative data from local markets on transactions, interactions, processes, and embedded services [72] and crosscheck information obtained from other sources. It is also used for collecting related information about infrastructure, hygienic conditions, and the attitude of those interviewed in the survey. The research steps are presented in Figure 1.

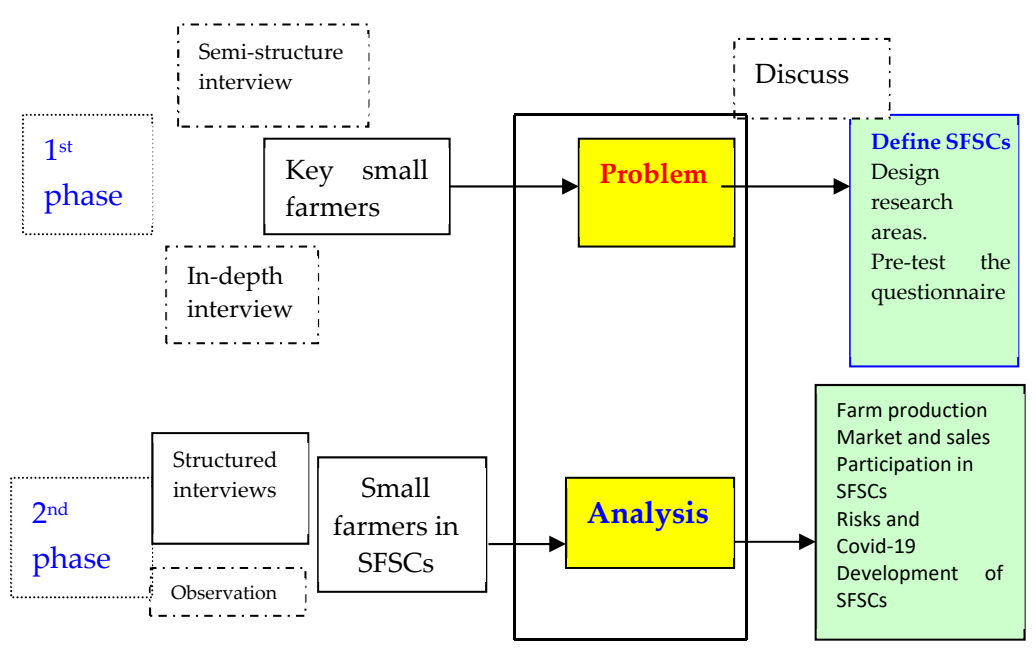

Figure 1. Research steps. Source: Own Illustration. 
Non-probability sampling method [73] with specific sample numbers:

$$
\mathrm{SS}=\frac{\mathrm{Z}^{2} \times(\mathrm{p} \times(1-\mathrm{p}))}{e^{2}}=\frac{1.96^{2} \times(0.08 \times(1-0.08))}{0.03^{2}}=314
$$

In which: $\mathrm{Z}$ is the standard distribution statistical value. With $95 \%$ confidence, $\mathrm{Z}=$ 1.96. p: the probability of selection. With the limitation of study time, we choose $p=8 \%, e$ : level of error, $e=3 \%$.

The target survey group was small farmers, who created and sold products in SFSCs, meaning, there was a maximum of one intermediate between producers and endconsumers. The interview was carried out with the head of the farms within one and a half hours, and at three regions of Vietnam: the north, the central, and the south, in the third quarter of 2020. In each region, we chose one representative province/city: Hanoi City in the north; Dak Lak province in the central, and Dong Thap province in the south. In each province, we chose two representative districts, and in each district, one representative commune was chosen. In each commune, 70 small farmers were interviewed. 420 farmers were interviewed, and after cleaning, 338 samples (80.5\%) were used for processing and analysis. Information was also collected from 60 actors ( 20 actors in each region, such as local shop owners, collective kitchen, traders) and relevant stakeholders such as local authorities. After cleaning, data were processed by Stata 14 software, and presented in tables, figures.

Grade point average calculation method (GPA) was used to determine the level of farmer's satisfaction in joining the SFSCs.

$$
\text { Distance value }=\frac{\text { Maximum }- \text { Minimum }}{n}=\frac{5-1}{5}=0.8
$$

The mean value was calculated by the number of farmers at each level of satisfaction and the coefficient of each level and was compared with the intervals in the scale of importance (Table 1) to find its meaning.

Table 1. The interval of the level and the meaning.

\begin{tabular}{ccc}
\hline Mean & \multicolumn{2}{c}{ Level } \\
\hline $1.00-1.80$ & Never & Very dissatisfied \\
\hline $1.81-2.60$ & Rarely & Dissatisfied \\
\hline $2.61-3.40$ & Sometimes & Neutral \\
\hline $3.41-4.20$ & Often & Satisfied \\
\hline $4.21-5.00$ & Frequently & Very satisfied \\
\hline
\end{tabular}

\section{Results}

\subsection{Characteristics and Participation of Small Farmers in the Short Food Supply Chains}

The SFSCs in the survey sample in Vietnam are presented in Figure 2. There were two main functions in the chain only: production and distribution. These functions were implemented by two main actors: producers (farmers, cooperatives); and distributors-marketeers (traders, local shops, etc.), who participated directly in value-added creation along the chain. The role of distributor and marketeer was not separated clearly. A distributor could do a function of a marketeer, which means he/she could sell products in or to a market. 


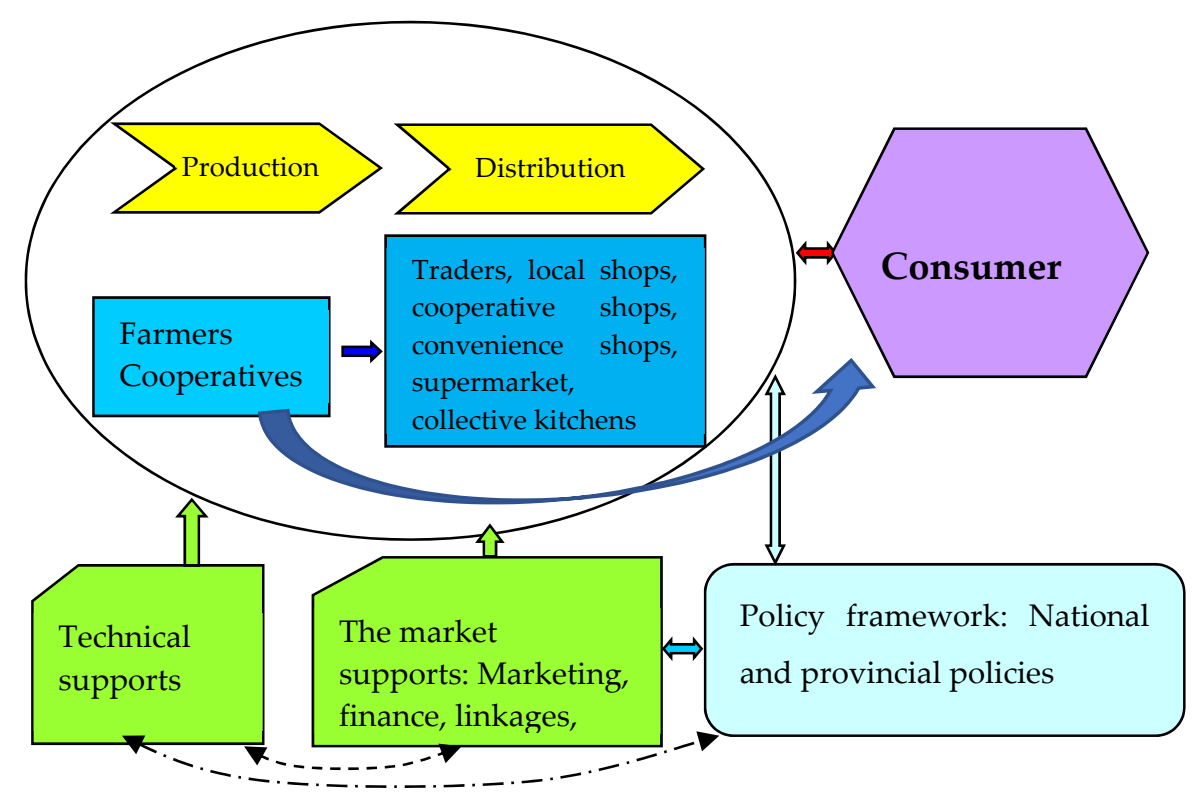

Figure 2. The short food supply chains (SFSCs) in the survey sample in Vietnam. Source: Own illustration.

There were 263 out of 338 surveyed farmers who grew fruit, accounting for $77.8 \%$. The proportion of farmers who grew vegetables, rice, produced meat, egg, and others were $28.1 \%, 5.0 \%, 8.3 \%, 4.7 \%$, and $17.1 \%$, respectively. These farmers and their cooperatives were the major and starter actors who played the most important role in the chain. They created products and provided them to distributors or directly to end-consumers. In some special cases, there were some eco-tourism farms/enterprises to do this function. In the distribution stage, there were many participants such as traders, local shops, convenience shops, local market/supermarket, or collective kitchens. They linked producers and consumers, making a smooth flow of goods. They were the most powerful actors in the chain and became the decision-making actors for the chain.

Some stakeholders did not participate directly in value-added creation along the chain but affected or had an interest in the chain operation. Some organizations and projects from the national or provincial levels supported the farmers or their cooperatives. The veterinarians, plant protection organizations, and outreach initiatives helped farmers to deal with their technical problems such as disease control, protecting production from harsh conditions, preventing them from suffering the effects of natural disasters, etc. Financial institutions such as the Bank for Agriculture and Rural Development, along with the Policy and Social Bank provided them with small loans. Universities and educational organizations provided support related to marketing, chain linkage, and farm management. The government and local authorities created the environment to produce food products through decisions, resolutions, directives, decrees, etc. However, the role of these stakeholders was not clear because the SFSCs was a new concept and there were only a few people interested in it in Vietnam.

Because the SFSCs were rather new in Vietnam, most of the farmers participated in the pilot chains that they learned from the Internet or elsewhere, and then they built a chain spontaneously. In addition, there were $9 \%$ of farmers who formed a chain themselves based on their working experience and relationships with consumers. Some farmers joined the chain thanks to the encouragement and support from projects and local authorities. The rest joined the chains thanks to other opportunities (sometimes incidental chance) such as a niche market of guava for a politician, or high-income consumers demand-based market for vegetable in Long Bien district, Hanoi City (Figure 3). 


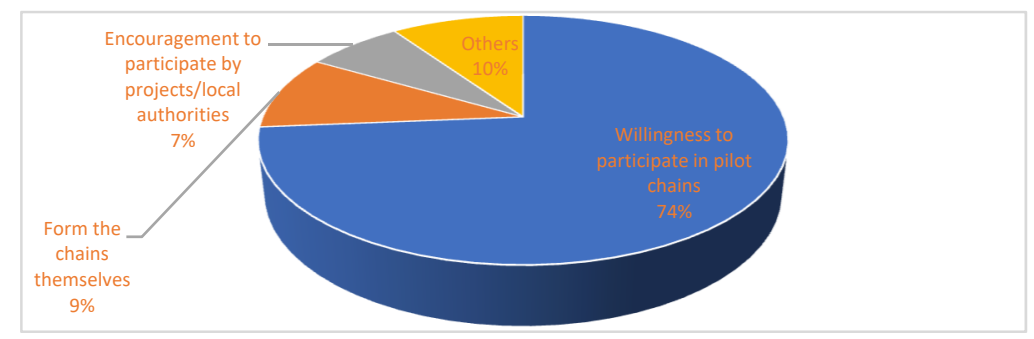

Figure 3. Participation of surveyed farmers in the SFSCs of Vietnam. Source: Survey results, 2020.

According to surveyed farmers' points of view, the local market was the area within 20 kilometers from their production areas $(28.4 \%$ response) or within their communes (29.6\% response). All of the farms $(100 \%)$ had more than half of their products $(53.6 \%)$ sold at the local market. Many of these farms sold all of their products (100\%) at the local market. There were $11.5 \%$ of farmers who sold their products at the local market daily, $13.6 \%$ sold weekly, $4.2 \%$ sold monthly and the rest sold quarterly. In Vietnam, small farmers were quite flexible in selling their products, they could simultaneously sell their products through many different channels [74]. Among the surveyed farms, many of them sold the products at their farm gates, some sold via local shops, others to processing factories, supermarkets, convenience shops, or collective kitchens. With the development of technology, the number of farms that sold their products online through E-commerce platforms or social networks was increasing. However, the major sales channels were to the local traders and local markets. The shares of products sold to other channels were rather low, less than $10 \%$ (Table 2).

There were two major distribution channels of products from the surveyed small farmers in Vietnam. In the first channel, farmers sold their products directly to end-consumers at their farm gates, at local markets, online, cash on delivery (farmers normally play the role of shippers), or a collective kitchen. In the second channel, there was one intermediary between producers and consumers. The middlemen might be local traders, local agricultural shops, local cooperative shops, convenience shops, local market/supermarkets, or collective kitchens (Figure 4).

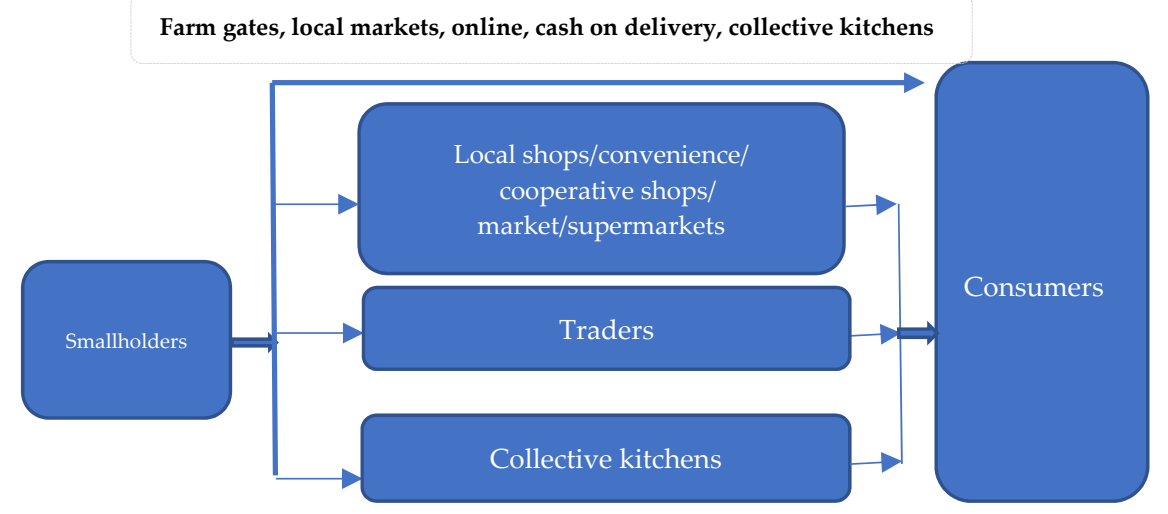

Figure 4. Distribution channels of the surveyed farms in SFSCs of Vietnam. Source: Survey results, 2020. 
Table 2. Share of products by sales channels.

\begin{tabular}{|c|c|c|c|c|c|c|c|c|c|}
\hline \multirow[t]{2}{*}{ Sales Channels } & \multirow{2}{*}{$\begin{array}{c}\text { Obs } \\
\text { Farm }\end{array}$} & \multicolumn{2}{|c|}{$<10 \%$} & \multicolumn{2}{|c|}{$10-20 \%$} & \multicolumn{2}{|c|}{$20-50 \%$} & \multicolumn{2}{|c|}{$\geq 50 \%$} \\
\hline & & Freq. & $\%$ & Freq. & $\%$ & Freq. & $\%$ & Freq. & $\%$ \\
\hline Farmgate & 301 & 189 & 62.79 & 64 & 21.26 & 24 & 7.97 & 24 & 7.97 \\
\hline Local market & 224 & 147 & 65.62 & 15 & 6.7 & 34 & 15.18 & 28 & 12.5 \\
\hline $\begin{array}{l}\text { Cash on } \\
\text { delivery }\end{array}$ & 177 & 172 & 97.18 & 4 & 2.26 & 0 & 0 & 1 & 0.56 \\
\hline $\begin{array}{l}\text { Collective } \\
\text { kitchen }\end{array}$ & 179 & 172 & 96.09 & 3 & 1.68 & 1 & 0.56 & 3 & 1.68 \\
\hline Social network & 177 & 172 & 97.18 & 2 & 1.13 & 1 & 0.56 & 2 & 1.13 \\
\hline Local trader & 332 & 63 & 18.98 & 9 & 2.71 & 14 & 4.22 & 246 & 74.1 \\
\hline
\end{tabular}


Almost all farmers sold their fresh products with preliminary processing (98\%). There was only $2 \%$ of farms that processed products before selling. Although most of them recognized the importance of advertising and labeling the products, there was only $17.8 \%$ of farmers advertising and nearly $3 \%$ labeling products before selling. Three major reasons to explain why they did not label their products before selling were "no request from consumer" (42.3\%), "high cost of labeling" (24.3\%), "do not know how to label" (16.6\%).

\subsection{Sustainable Benefits of the Short Food Supply Chains to Small Farmers}

\subsubsection{Economic Benefits}

The SFSCs created many economic benefits for producers, consumers, and the local community [10]. For producers in Vietnam, especially small farmers, participating in the SFSCs stabilized the input, output price, and revenue; created sustainable income; and increased satisfaction and confidence. According to farmers' response, before joining the SFSCs, $82 \%$ of them had faced the situation of fluctuated price; $66.3 \%$ of farmers had faced difficulty due to output price reduction, $21.3 \%$ of them had experienced difficulty in sales. However, after participating in the SFSCs, this situation was much improved (76.3\%). In 2019, the average profit of the farms was 106.2 million Vietnam Dong (VND) (Dong (VND) is the currency of Vietnam. Exchange rate: $1 \mathrm{USD}=23,040 \mathrm{VND}$, consulted on 12 September 2020. Exchange rates (vietcombank.com.vn)). Some farms obtained losses, but some farms innovated, applied advanced technology, developed niche markets, managed farms well, and achieved high profits. The highest profit farm achieved 2 billion VND.

On average, income from the surveyed farmers in the SFSCs occupied $71.8 \%$ of total farm income. The lowest proportion was $5 \%$ while there were many farms whose total income came entirely from the SFSCs (Table 3). There were $35.21 \%$ of farms that reported that their income improved after joining the chain.

Table 3. Farmers' profit and share of income from SFSCs.

\begin{tabular}{|c|c|c|c|c|c|}
\hline Variable & Obs & Mean & Std. Dev. & Min & Max \\
\hline $\begin{array}{c}\text { Share of } \\
\text { income from } \\
\text { short food } \\
\text { supply chain }\end{array}$ & 328 & 71.81402 & 29.65117 & 5 & 100 \\
\hline $\begin{array}{l}\text { Profit (1000 } \\
\text { VND) }\end{array}$ & 291 & $106,205.4$ & $247,726.3$ & $-10,000$ & $2,000,000$ \\
\hline
\end{tabular}

One of the farmers who grew guava in Phuc Loi commune, Long Bien district, Hanoi City, expressed in one of the interviews conducted:

"Since joining the short guava supply chain, guava price of my farm and others in the commune is more stable and much higher than in the market. In some cases, it is two or three times higher than the market price. This increases our income. My profits are nearly 2 times higher than those of other guava farmers in other areas. Therefore, I am very satisfied with the production."

Another farmer who grew vegetables in the Dong Du commune, Long Bien district, Hanoi City, expressed:

"In the past, I planted vegetables and often faced the situation with the good season price loss, or good price while cropping failures. Also, the input price was high, output price fluctuated or decreased by traders. Many times, we could not sell our products and had to use vegetables to feed our animals such as chickens, pigs, or cows. Since joining this SFSC, I concentrate on producing to ensure the quality of products and do not have to worry about selling, and the price is stable. My income improves much. I and about 40 farmers are very satisfied to participate in this chain. We are very happy." 
A farmer growing organic coffee in Buon Me Thuot city, Dak Lak province, said: "Three years ago, I grew conventional coffee and often suffered from the situation of decreasing the price by traders. The output price was low while the input price was high, therefore, I got losses many times. Sometimes, I became discouraged and wanted to stop the farming job. After joining this organic coffee supply chain, although we have to work harder and production costs are higher, we get a much higher output price, easy-to-sell products, and higher income. Nowadays, many of our neighbors join the SFSCs."

In general, the surveyed farmers felt satisfied with their income, job, social respect, and plant types (Table 4). The only factor that they were dissatisfied with was "the consumer/consumption market." There were 146 people (43.2\%) who complained that local demand was still small.

Table 4. Farmers' satisfaction when participated in the SFSCs.

\begin{tabular}{ccccc}
\hline Factors & Obs & Mean & Std. Dev. & Meaning \\
\hline Income & 332 & 3.41 & 1.15 & Satisfied \\
Job & 330 & 3.65 & 0.80 & Satisfied \\
Social respect & 322 & 3.54 & 0.74 & Satisfied \\
Plant types & 331 & 3.81 & 0.68 & Satisfied \\
Consumption & 330 & 2.51 & 1.19 & Dissatisfied \\
market & & & & \\
\hline
\end{tabular}

Source: Survey results, 2020.

A farmer in Dak Lak province explained the reason for the dissatisfaction with the consumer market in one of the interviews conducted:

"The consumer market for products in the SFSCs is still limited in Vietnam, only a small proportion of consumers know about it."

\subsubsection{Social Benefits}

In addition to the economic contribution, the SFSCs generate social benefits for small farmers. Firstly, it creates stable jobs for them. Survey results showed that the chain created jobs not only for farmers themselves, but each farm also created 2.4 full-time jobs, 5.6 part-time jobs, or approximately 3.41 full-time equivalent jobs for rural people.

A farmer joining a short high-quality-rice supply chain in Lam Dong province said:

"Working on a farm is hard. Previously, many people in my village had to quit their jobs, left their villages to do manual work in the industrial zones, or became street vendors in big cities because they could not sell the products or always get lost. Since joining the short supply chain of high-quality-rice, we do not worry about the output market. The price is stable. In brief, this chain creates many stable jobs for us, and improve our lives."

Secondly, SFSCs could eliminate the situation of gender discrimination in rural areas of Vietnam. This still exists in the world of work, as big farms prefer to recruit men rather than women. However, the surveyed farms were likely to recruit women to work in their farms, with more than $60 \%$ of jobs generated for women.

A commune government official shared about the benefits of developing SFSCs for women:

"Development of the SFSCs not only creates jobs and stable incomes for women, but also creates better conditions to improve the quality of life, contributes and supports women in our commune to develop comprehensively in knowledge, communication skills, social activity, and health care. They are more confident in life and have a better capacity to participate in making decisions about their own family and in their village." 
Third, the development of SFSC s contributes significantly to improve livelihood for ethnic minority farmers. The survey results showed that there were many people from ethnic minorities who obtained benefits from participating in the SFSCs, such as the Tay, the Dao people in the northern province; the E De and the Nung people in the central province; and the Khmer in the southern province of Vietnam.

One farmer in an SFSC associated with Kotam tourism farm in Buon Me Thuot city, Dak Lak province, expressed:

"Since we developed this chain, we have created direct jobs with stable income for more than 60 employees of the E De ethnic group, of which, more than half are female. I am a person who always wants to preserve the unique culture of the E De people. We often organize activities to promote and develop the culture of the E De people; connect people, and bring the E De culture to everyone. We also have generated indirect jobs for many surrounding farmers who supply additional products to the chain."

Fourth, participating in the SFSCs through cooperatives facilitates and brings people in the village together, creates opportunities for farmers to collaborate, start-up, and get support from local authorities or organizations.

Recently, there were $65 \%$ of households / farms with more than 10 million farmers in Vietnam participated in cooperatives or associations [75], especially agricultural cooperatives. Joining the SFSCs through cooperatives has been a great help to farmers. There were 107 among 338 surveyed farmers (31.66\%) who joined the cooperatives or associations. Among those farmers, 11 people started up their cooperatives. 134 people got support from national and/or local government, 8 people joined and got support from cooperatives, and 45 people got other benefits such as training, coaching, and sharing experience.

Finally, participation in the chain also contributed to strengthening farmers' capacity or power when negotiating with distribution intermediaries $(25.74 \%)$, and it also enlarged their output market (27.81\% response).

\subsubsection{Environmental Benefits}

SFSCs not only created economic and social benefits, but also generated environmental benefits for small farmers. It contributed to the improvement of efficiency and mindset on green, organic, and clean production for farmers. To join SFSCs, farmers had to strictly comply with safety standard production, including regulations on the safe use of veterinary drugs, protection chemicals, preservatives, food sanitary and phytosanitary materials. Among the surveyed farms, 204 people (60.4\%) followed these safe standard farming procedures; $6 \%$ of the farms applied best production practice to ensure their and society's better living environment by non-use of chemical production models in the greenhouse, net house, or organic models; $93.2 \%$ of farms did not use preservatives in the process of preserving agricultural products; $23 \%$ of farms did not use chemical fertilizers and pesticides. These production models provided safe agricultural products that ensure food sanitary and phytosanitary to customers. More importantly, farmers themselves obtained benefits from reduced chemical exposure, thus, their health was safe, their living environments, including air, land, and water environment were fresher, healthier, and guaranteed. Society also obtained benefits through ensuring biodiversity, minimizing habitat destruction, reducing soil and water pollution from excessive pesticides and fertilizers.

A farmer participating in a short chain of vegetables in Duong Xa commune, Gia Lam district, Hanoi City said:

"To join this short supply chain of safe vegetables, members must understand and practice the correct food safety and hygiene standards, ensure to use the right kind, at the right time, with the right dose of safe and suitable fertilizers and pesticides. Before, we did not know well, used unsuitable or over-used of chemicals so that, many species disappeared such as leeches, insects, ... . Human health was also affected, many people suffered from skin diseases or 
respiration problems. Since joining this chain, we use chemicals properly, our living environment is guaranteed, peoples' health becomes improved."

Participating in short supply chains of agricultural products for sale in the local market contributed to the reduction of transportation costs and carbon emissions by reducing energy use during transportation. Due to the short distance from producers to end-consumers, the major means of product transportation from producers to consumers' areas were motorbikes (55.3\%) that use much less petrol than big transportation such as vans and trucks. There were $25 \%$ of farmers who use means of transportation without using any petrol such as on foot or bike. There were only $12.4 \%$ of them who used a small truck to transport products, of which there were only $0.6 \%$ using refrigerated trucks in case of transporting the easily spoiled products such as meat (Figure 5).

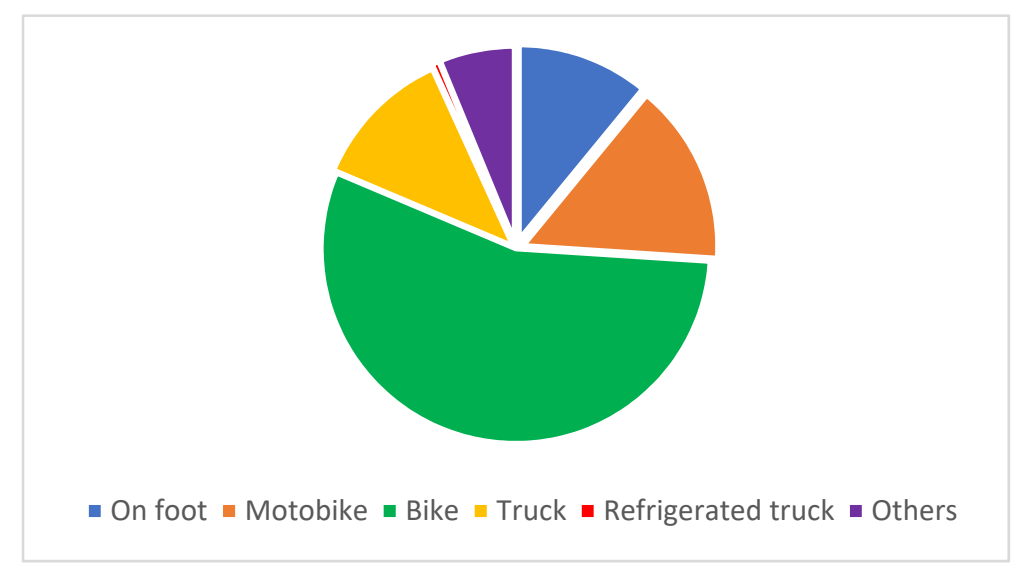

Figure 5. Means of transportation. Source: Survey results, 2020.

\subsection{Impact of Coronavirus Pandemic}

The SFSCs in the survey sample showed some evidence of benefits to small farmers. However, to join the SFSCs, farmers faced some difficulties. According to the respondents, the biggest difficulties they often encountered included: capital shortage (34.62\%), labor shortage $(24.85 \%)$, water shortage $(24.26 \%)$, and transportation difficulty $(6.5 \%)$. It was more difficult for the farmers in the mountainous areas.

Especially in 2020, the COVID-19 pandemic posed a negative impact on small farmers in general and small farmers in the SFSCs, in particular. There were 142 people (43.03\%) who responded that they faced very difficulties, and 104 people (31.52\%) faced difficulty in sales during the COVID-19 pandemic. COVID-19 also affected the small farmers' income. There were 130 farmers $(38.46 \%$ ) who responded that their income decreased due to the pandemic.

In response to the COVID-19 outbreak, many farmers tried to reduce the negative impact by producing and providing food products to satisfy the daily demand of the customers. There were 39 people $(11.54 \%)$ who changed from direct to indirect sale method, 9 people $(2.66 \%)$ who changed from traditional sale method to selling on social networks, 8 people $(2.37 \%)$ who changed to sell in the local vegetable shop, and 29 people (8.58) who changed to the other sale methods, including E-commerce platform.

The COVID-19 pandemic also impacted the approach and orientation of the small farmers in Vietnam. Before the pandemic, there had been only 38 farmers $(11.3 \%)$ who had participated in ecotourism and collective kitchen SFSCs. During COVID-19, the demand for joining these chains increased to 63 farmers (18.6\%). The number of farmers who would like to join these chains shortly was 190 (56.2\%), and 72 other people $(21.3 \%)$ would consider joining these chains.

Moreover, the COVID-19 pandemic also affected the mindset of farmers on production and marketing methods. Previously, there had been only $6 \%$ of farmers who applied and practiced the production model without using chemicals such as greenhouse, net house, and 
organic production models. By the time of the survey (during the COVID-19 pandemic), the numbers of farmers who would like to apply the organic production model were 224 people $(66.3 \%)$. The numbers of farmers who advertised and labeled their products before COVID-19 were 60 and 9 people, respectively. During the COVID-19 pandemic, 90 people advertised and 93 people labeled their products. Many of them would like to develop their product brands.

\subsection{Demand for the Support to Develop the SFSCs Sustainability}

According to farmers' points of view, it was necessary to support the SFSCs in Vietnam. They expressed that to promote the chains, both production and sales needed support. They evaluated four main factors that needed to improve the sales: "to be trained in marketing," "to be connected to local retailers and consumers," "to be supported on product branding," and "to participate in the local distribution chain." (Table 5) There were 261 people $(77.22 \%)$ who needed the support of convenient sale points; 99 people $(29.3 \%)$ had a demand for the support of market information; 81 people $(24.0 \%)$ desired to support product labels and brand; and 67 people $(19.8 \%)$ wanted to support in advertising and promoting their products.

Table 5. Evaluation level of demand for support in sales.

\begin{tabular}{|c|c|c|c|c|}
\hline Criteria & Obs & Mean & Std. & Conclusion \\
\hline $\begin{array}{l}\text { Be trained in } \\
\text { marketing }\end{array}$ & 338 & 3.5 & 1.31 & Important \\
\hline $\begin{array}{l}\text { Be connected to } \\
\text { local retailers } \\
\text { and consumers }\end{array}$ & 338 & 4.0 & 0.99 & Important \\
\hline $\begin{array}{c}\text { Be involved in } \\
\text { product } \\
\text { branding }\end{array}$ & 338 & 3.9 & 1.00 & Important \\
\hline $\begin{array}{c}\text { Be participated } \\
\text { in the local } \\
\text { distribution } \\
\text { chain }\end{array}$ & 338 & 4.0 & 0.98 & Important \\
\hline
\end{tabular}

To enhance the production, the farmers evaluated "to be trained in organic production" at the important level. There were 120 people $(35.50 \%)$ who needed the information and guideline documents for organic production, and 78 people $(23.08 \%)$ who would like to support the organic production procedure. Moreover, 85 farmers $(25.15 \%)$ demanded a loan from banks and financial institutions for their investment. There were 171 people $(50.59 \%)$ who wanted to support improving skills of good practice in tourism farming. Some people needed other supports such as an Internet system $(9.17 \%)$, vehicles for product transportation $(6.51 \%)$, etc.

\section{Discussion}

The sales method of the survey sample in the SFSCs via a local market in Vietnam (within a commune, a district with the producers) was similar to previous research ideas [76], but the geographical distance in Vietnam (within $20 \mathrm{~km}$ ) seems shorter than those of others $[30,77]$. Although these sales methods have existed from the past in Vietnam, most of them were in unorganized local sources like wet markets and street vendors. The sales method through SFSCs with good linkages among chain actors ensures the good quality of products, brings more benefits not only for farmers but also for consumers. The geographical distance in the surveyed short food supply chain in Vietnam was shorter than others because the concept of the SFSCs is still new in Vietnam, most small farmers 
joined the short food supply chain based on their relationship with neighboring areas and in the first period of development.

The sales through farm gates, local product shops, convenience shops, collective kitchens, E-commerce platforms, or the social networks of the small farmers in the survey sample of the SFSCs in Vietnam was similar to some previous studies $[1,3,4,78,79]$. However, a difference from developed countries like France, Austria, Hungary, Italy, etc. [3,8,69] is that the major channels of sales from the survey sample in Vietnam were through the local traders and markets. This implies that local traders will have a stronger power on setting products' prices and they will have more benefit, while small farmers will be more vulnerable because they will become accepted price actors. Almost all the farms sold their fresh products with preliminary processing, and most of them (97\%) did not label products before selling. In the integrating world, in order to compete with other participants in the market, small farmers should think about improving the value-added for their products through processing and labeling the products.

The SFSCs from the survey sample in Vietnam created economic benefits to small farmers such as stabilizing the input, output price, and revenue, creating sustainable income, and increasing satisfaction and confidence for them as previous research results $[20,21]$. It also created stable jobs, strengthened linkages, and collaborate with the people in the villages similar to the previous studies $[21,51,54]$. In addition, it contributed to improving the situation of gender discrimination in rural areas of Vietnam, enhancing livelihood for ethnic minority farmers, and strengthening farmers' negotiation capacity or power when discussing with distribution intermediaries. Although this benefit should be proven by more methodical and full research, this could be an additional value of the SFSCs in the developing countries with multi-ethnic minority groups like Vietnam.

Similar to other researchers' results, the SFSCs created environmental benefits for society [56]; the SFSCs in the survey sample in Vietnam contributed to the change of the orientation and action of farmers in Vietnam to be greener and cleaner for a good living environment by non-use or less-use chemicals production models. It also helped to reduce carbon emissions by using no or fewer energy-consuming transportation means, for example, farmers who went on foot, rode bicycles, or used motorbikes. However, it is necessary to do more and full research in the future to gather enough information to prove that.

\section{Conclusions}

The SFSCs is almost a new concept in Vietnam and does not attract much attention. The survey sample results showed that the chain was very simple but the initial results provided some evidence of its benefit to the sustainable development of economic, social, and environmental aspects. The SFSCs with good linkages among chain actors to ensure the good quality of products brought more benefits not only for farmers but also for consumers and local communities.

In Vietnam, besides developing global supply chains, the development of SFSCs will be an alternative method to promote the sustainable development of the economy in general, and small farmers, in particular. To do this, the government had better pay attention to create the investment environment for the development of the SFSCs as follows:

Provide suitable regulations to adjust the new mechanisms and operations of the chain participants such as food safety and hygiene regulations to ensure food quality; the "Green" production procedure to enable the production of environmentally friendly items; and trade rules to motivate the public sector to purchase local and environmentally friendly products, for example, the government could require or encourage a minimum percentage of fresh local foods in school meals.

Develop regulations on local brands such as Rules of Origin Protection and Geographical Indication Protection to protect local products with certain characteristics and promote the recognition and trust of consumers. 
Establish policies to support marketing, trade, and product promotion. Farmers are often the main actors in the SFSCs, but they face great difficulties in marketing and promoting products. Therefore, the supportive policies on marketing and product promotion help them a lot when participating in the short chains, where they directly introduce, advertise, and sell products to consumers. There are some kinds of supporting aspects such as logistic support for local markets; technical assistance for creating marketing platforms; negotiation capacity; accessing marketing and production services; developing collective retail stores; assistance to facilitate product certifications; development of product logos, trademarks, and branding.

Create financial incentives for the chain actors, especially for small farmers to invest in the new production and marketing methods.

Support for research and training in the SFSCs to promote the thinking and behavior of actors.

This is a small research, initially giving some observation about the benefits of the SFSCs in Vietnam. In order to have a full and accurate explanation about the SFSCs in Vietnam, it is necessary to have more methodical and full research in the future. This study demonstrates an opportunity for the research and adoption of SFSCs in the context of increasing domestic demand for greater diversity and quality in food products from the fast-growing middle-class consumers in Vietnam.

Author Contributions: Conceptualization, methodology, and supervision, T.N.B., T.T.H.L. (Thi Thu Huong Le), V.P.N., T.T.H.L. (Thi Thanh Hao Le), T.T.H.T., N.M.N., T.K.O.L., T.K.O.N., T.T.T.N., H.V.D., T.N.T.D., T.H.N.V., A.H.N., V.H.B., H.C.H., P.L.; investigation, T.N.B., A.H.N., V.P.N., V.H.B., H.C.H.; writing - original draft preparation, T.T.H.L. (Thi Thanh Hao Le); validation, formal analysis, resources and data curation, writing — original draft preparation, writing-review and editing, T.N.B.; software, T.T.H.L. (Thi Thu Huong Le). All authors have read and agreed to the published version of the manuscript.

Funding: This research was funded by Research funded by National Foundation for Science and Technology Development of Vietnam (01/2019/NCUD).

Institutional Review Board Statement: Not applicable.

Informed Consent Statement: Not applicable.

Data Availability Statement: Not applicable.

Acknowledgments: We would like to acknowledge the support from the National Foundation for Science and Technology Development of Vietnam.

Conflicts of Interest: The authors declare no conflict of interest.

\section{References}

1. Renting, H.; Marsden, T.; Banks, J. Understanding Alternative Food Networks: Exploring the Role of Short Food Supply Chains in Rural Development. Environ. Plan. A 2003, 35, 393-411. [CrossRef]

2. Deverre, C.; Lamine, C. Les Systèmes Agroalimentaire Alternatifs: A Revue de Travaux Anglophones en Sciences Sociales. Économie Rural. Agric. Aliment. Territ. 2010, 317, 57-73. [CrossRef]

3. Aguiar, L.C.; DelGrossi, M.E.; Thome, K.M. Short food supply chain: Characteristics of a family farm. Rural Sociol. 2018, 48, e20170775. [CrossRef]

4. Marsden, T.; Banks, J.; Bristow, G. Food Supply Chain Approaches: Exploring their Role in Rural Development. Sociol. Rural. 2000, 40, 424-438. [CrossRef]

5. John, T.M.; Theodore, P.S.; Matthew, B.M. Why Global Supply Chain Management? In Handbook of Global Supply Chain Management; SAGE Publishing: Newbury Park, CA, USA, 2007; Available online: https:/ /www.researchgate.net/publication/316349965_ Why_Global_Supply_Chain_Management (accessed on 2 February 2021).

6. Sheffi, Y.; Bovet, D. The Brave New World of Supply Chain Management. In Supply Chain Management Review; Springer: Berlin/Heidelberg, Germany, 1998; Volume 2, pp. 14-22.

7. Galli, F.; Brunori, G. Short Food Supply Chains as Drivers of Sustainable Development: Evidence Document; Document Developed in the Framework of the FP7 Project FOODLINKS (GA No. 265287); Laboratorio di Studi Rurali Sismondi: Pisa, Italy, 2013; ISBN 978-88-90896-01-9. 
8. Moya, K.; Laura, V.; Ulrich, S.; Bálint, B.; Liz, T.; Trish, E.-W.; Elizabeth, B.; Gemm, S.; Matthew, B. Short Food Supply Chains and Local Food Systems in the EU. In A State of Play of Their Socio-Economic Characteristics; Scientific and Policy Reports; European Commission, Joint Research Centre, Institute for Prospective Technological Studies: Seville, Spain, 2013.

9. Barry, C. Commercialisation Des Produits Agricoles. In Un Producteur sur Cinq Vend en Circuit Court; Agreste Primeur: Paris, France, 2012; No. 275; 4p, Available online: http:/ /46.29.123.56/IMG/pdf_primeur275.pdf (accessed on 2 February 2021).

10. Malak-Rawlikowska, A.; Majewski, E.; Wąs, A.; Borgen, S.O.; Csillag, P.; Donati, M.; Freeman, R.; Hoàng, V.; Lecoeur, J.-L.; Mancini, M.C.; et al. Measuring the economic, environmental, and social sustainability of short food supply chains. Sustainability 2019, 11, 4004. [CrossRef]

11. Boutry, O.; Ferru, M. Apports de la méthode mixte pour une analyse globale de la durabilité des circuits courts. Développement Durable Territ. 2016, 7. [CrossRef]

12. Irene, C. Is the short food supply chain an efficient solution for sustainability in food market? Agric. Agric. Sci. Procedia 2016, 8 , 402-407.

13. Vittersø, G.; Torjusen, H.; Laitala, K.; Tocco, B.; Biasini, B.; Csillag, P.; de Labarre, M.D.; Lecoeur, J.-L.; Maj, A.; Majewski, E.; et al. Short Food Supply Chains and Their Contributions to Sustainability: Participants' Views and Perceptions from 12 European Cases. Sustainability 2019, 11, 4800. [CrossRef]

14. Lucian, T. Functional Short Food Supply Chains in the Field of Romanian Rural Tourism. Case Study: Harghita and Neamt counties. Ecoforum 2015, 4, 210-217.

15. Tanasa, L.; Bruma, I.-S.; Dobos, S. The Role of Short Food Supply Chains in the Development of Small-Scale Local Producer Case Study: Harghita County. In Proceedings of the Agrarian Economy and Rural Development-Realities and Perspectives for Romania, 6th ed.; International Symposium: Bucharest, Romania, 20 November 2015.

16. Roep, D.; Wiskerke, H. Nourishing Networks Fourteen Lessons about Creating Sustainable Food Supply Chains; Rural Sociology Group of Wageningen University and Reed Business Information: Wageningen, The Netherlands, 2006.

17. DuPuis, M.; Goodman, D. Should we go 'home' to eat? Toward a Reflective Politics of Localism. J. Rural Stud. 2005, 21, 359-371. [CrossRef]

18. Van Der Ploeg, J.D.; Renting, H.; Brunori, G.; Knickel, K.; Mannion, J.; Marsden, T.; De Roest, K.; Sevilla-Guzman, E.; Ventura, F. Rural Development: From Practices and Policies towards Theory. Sociol. Rural. 2000, 40, 391-408. [CrossRef]

19. Marsden, T.; Banks, J.; Bristow, G. The Social Management of Rural Nature: Understanding Agrarian-Based Rural Development. Environ. Plan. A 2002, 34, 809-825. [CrossRef]

20. Pearson, D.; Henryks, J.; Trott, A.; Jones, P.; Parker, G.; Dumaresq, D.; Dyball, R. Local Food: Understanding Consumer Motivations in Innovative Retail Formats. Br. Food J. 2011, 113, 886-899. [CrossRef]

21. Sage, C. Social Embeddedness and Relations of Regard: Alternative 'Good Food' Networks in South West Ireland. J. Rural Stud. 2003, 19, 47-60. [CrossRef]

22. Alonso, A. Farmers' involvement in Value-Added Produce: The Case of Alabama Growers. Br. Food J. 2011, 113, 187-204. [CrossRef]

23. Broderick, S.; Wright, V.; Kristiansen, P. Cross-Case Analysis of Producer-Driven Marketing Channels in Australia. Br. Food J. 2011, 113, 1217-1228. [CrossRef]

24. Christopher, M. Logistics and Supply Chain Management: Strategies for Reducing Costs and Improving Services; Pitman Publishing: London, UK, 1992.

25. Bowersox, D.J.; Closs, D.J. Logistical Management: The Integrated Supply Chain Process; McGraw-Hill: New York, NY, USA, 1996.

26. Lambert, D.M.; Emmelhainz, M.A.; Gardner, J.T. Building Successful Logistics Partnerships. J. Bus. Logist. 1999, $20,165-181$.

27. Mentzer, J.T.; DeWitt, W.; Keebler, J.S.; Min, S.; Nix, N.W.; Smith, C.D.; Zacharia, Z.G. Defining Supply Chain Management. J. Bus. Logist. 2001, 22, 1-24. [CrossRef]

28. Christopher, M.C. From Brand Values to Customer Value. J. Mark. Pract. Appl. Mark. Sci. 1996, 2, 55-66. [CrossRef]

29. Anderson, M.G.; Katz, P.B. Strategic Sourcing. Int. J. Logist. Manag. 1998, 9, 1-13. [CrossRef]

30. Birou, L.M.; Fawcett, S.E.; Magnan, G.M. The Product Life Cycle: A Tool for Functional Strategic Alignment. Int. J. Purch. Mater. Manag. 1998, 34, 37-51. [CrossRef]

31. Lummus, R.R.; Vokurka, R.J.; Alber, K.L. Strategic Supply Chain Planning. Prod. Inventory Manag. J. 1998, 39 , 49-58.

32. Ketchen, D.J.; Guinipero, L. The Intersection of Strategic Management and Supply Chain Management. Ind. Mark. Manag. 2004, 33, 51-56. [CrossRef]

33. Ketchen, D.J., Jr.; Hult, G.T.M. Bridging Organization Theory and Supply Chain Management: The Case of Best Value Supply Chains. J. Oper. Manag. 2007, 25, 573-580. [CrossRef]

34. Kalwani, M.U.; Narayandas, N. Long-term Manufacturing-Supplier Relationships: Do They Pay Off for Supplier Firms? J. Mark. 1995, 59, 1-16. [CrossRef]

35. Forza, C. Achieving Superior Operating Performance from Integrated Pipeline Management: An Empirical Study. Int. J. Phys. Distrib. Logist. Manag. 1996, 26, 36-63. [CrossRef]

36. Narasimhan, R.; Jayaram, J. Causal Linkages in Supply Chain Management: An Exploratory Study of North American Manufacturing Firms. Decis. Sci. 1998, 29, 579-605. [CrossRef]

37. Salvador, F.; Forza, C.; Rungtusanatham, M.; Choi, T.Y. Supply Chain Interactions and Time-Related Performances: An Operations Management Perspective. Int. J. Oper. Prod. Manag. 2001, 21, 461-480. [CrossRef] 
38. Boyer, K.; Swink, M.; Rosenzweig, E.D. Operations Strategy Research in the POMS Journal. Prod. Oper. Manag. $2005,14,442-449$. [CrossRef]

39. Rungtusanatham, M.; Salvador, F.; Forza, C.; Choi, T.Y. Supply-Chain Linkages and Operational Performance: A Resource-based Perspective. Int. J. Oper. Prod. Manag. 2003, 23, 1084-1099. [CrossRef]

40. Barratt, M.A.; Oliveira, A. Exploring the Experiences of Collaborative Planning Initiatives. Int. J. Phys. Distrib. Logist. Manag. 2001, 31, 266-289. [CrossRef]

41. Fawcett, S.E.; Magnan, G.M. The Rhetoric and Reality of Supply Chain Integration. Int. J. Phys. Distrib. Logist. Manag. 2002, 32, 339-362. [CrossRef]

42. Croson, R.; Donohue, K. Impact of POS Data Sharing on Supply Chain Management: An Experimental Study. Prod. Oper. Manag. 2003, 12, 1-11. [CrossRef]

43. Armistead, C.G.; Mapes, J. The Impact of Supply Chain Integration on Operating Performance. Logist. Inf. Manag. 1993, 6, 9-14. [CrossRef]

44. Berry, D.; Towill, D.R.; Wadsley, N. Supply Chain Management in the Electronics Products Industry. Int. J. Phys. Distrib. Logist. Manag. 1994, 24, 15-23. [CrossRef]

45. Gavirneni, S.; Kapuscinski, R.; Tayur, S. Value of Information in Capacitated Supply Chains. Manag. Sci. 1999, 45, 16-24. [CrossRef]

46. Lee, H.L.; Whang, S. Information Sharing in a Supply Chain. Int. J. Technol. Manag. 2000, 20, 373-387. [CrossRef]

47. Kent, J.L.; Mentzer, J.T. The Effect of Investment in Inter-Organizational Information Technology in a Retail Supply Chain. J. Bus. Logist. 2003, 24, 155-175. [CrossRef]

48. Mentzer, J.T.; Min, S.; Bobbitt, L.M. Toward a Unified Theory of Logistics. Int. J. Phys. Distrib. Logist. Manag. 2004, 34, 606-627. [CrossRef]

49. Patterson, K.A.; Grimm, C.M.; Corsi, T.M. Diffusion of Supply Chain Technologies. Transp. J. 2004, 43, 5-23.

50. Hendrickson, M.; Heffernan, W. Opening Spaces through Relocalization: Locating Potential Resistance in the Weaknesses of the Global Food System. Sociol. Rural. 2002, 42, 347-369. [CrossRef]

51. Kirwan, J. Alternative Strategies in the UK Agro-Food System: Interrogating the Alterity of Farmers' Markets. Sociol. Rural. 2004, 44, 396-415. [CrossRef]

52. Chiffoleau, Y. From Politics to Co-Operation: The Dynamics of Embeddedness in Alternative Food Supply Chains. Sociol. Rural. 2009, 49, 218-235. [CrossRef]

53. Cox, R.; Holloway, L.; Venn, L.; Dowler, L.; Ricketts-Hein, J.; Kneafsey, M.; Tuomainen, M. Common Ground? Motivations for Participation in a Community-Supported Agriculture Scheme. Local Environ. 2008, 13, 203-218. [CrossRef]

54. Hayden, J.; Buck, D. Doing Community Supported Agriculture: Tactile Space, Affect and Effects of Membership. Geoforum 2012, 43, 332-341. [CrossRef]

55. Pelletier, N.; Audsley, E.; Brodt, S.; Garnett, T.; Henricksson, P.; Kendall, A.; Kramer, K.J.; Murphy, D.; Nemecek, T.; Troell, M Energy Intensity of Agriculture and Food Systems. Annu. Rev. Environ. Resour. 2011, 36, 223-246. [CrossRef]

56. Seyfang, G. Avoding Asda? Exploring Consumer Motivations in Local Organic Food Networks. Local Environ. 2008, 13, 187-201. [CrossRef]

57. Coley, D.; Howard, M.; Winter, M. Food Miles: Time for a Re-Think. Br. Food J. 2011, 113, 919-934. [CrossRef]

58. Van Hauwermeiren, A.; Coene, H.; Engelen, G.; Mathijs, E. Energy Lifecycle Inputs in Food Systems: A Comparison of Local Versus Mainstream Cases. J. Environ. Policy Plan. 2007, 9, 31-51. [CrossRef]

59. Arias, P.; Hallam, D.; Krivonos, E.; Morrison, J. Smallholder Integration in Changing Food Markets; Food and Agriculture Organization of the United Nations: Italy, Rome, 2013; Available online: http:/ / www.fao.org/docrep/018/i3292e/i3292e.pdf (accessed on 2 February 2021).

60. Nigel, P. Smallholder Agriculture and Market Participation; Food and Agriculture Organization of the United Nations and Practical Action Publishing: Rugby, UK, 2017; Available online: http:/ /www.fao.org/3/a-i7841e.pdf (accessed on 2 February 2021).

61. Carlos, O.; Mark, L.; María, V.G.; Rupert, B.; Shaun, F. Identifying Market Opportunities for Rural Smallholder Producers; Centro Internacional de Agricultura Tropical: Cali, Colombia, 2007; Available online: https:/ /www.crs.org/sites/default/files/toolsresearch/identifying-market-opportunities-for-rural-smallholder-producers.pdf (accessed on 2 February 2021).

62. Magesa, M.M.; Michael, K.; Ko, J. Access and use of agricultural market information by smallholder farmers: Measuring informational capabilities. Electron. J. Inf. Syst. Dev. Ctries. 2020, e12134. [CrossRef]

63. Bui, T.N.; Tran, H.C. Actors' Benefit Analysis on Value Chain of Fresh Dairy Milk Chain in Vietnam. Econ. Dev. J. 2011, 169, 32-38.

64. Pearson, D.H.A.; Bailey, A. Sustainable Horticultural Supply Chain: The Case of Local Food Networks in the United Kingdom. In Proceedings of the XVIth International Symposium on Horticultural Economics and Management; Acta Horticulturae (831); ISHS: Leuven, Belgium, 2009; pp. 131-137. Available online: http:/ / centaur.reading.ac.uk/25348/ (accessed on 2 February 2021).

65. FAO. Horticultural Chain Management for Countries of Asia and the Pacific Region: A Training Package; RAP PUBLICATION 2009/06; FAO, Regional office for Asia and The Pacific: Bangkok, Thailand, 2009; Available online: http://www.fao.org/3/a-i0782e.pdf (accessed on 2 February 2021).

66. Roy, T.N. Supply Chain Management of Horticultural Crops. In Value Addition of Horticultural Crops: Recent Trends and Future Directions; Sharangi, A., Datta, S., Eds.; Springer: New Delhi, India, 2015; Available online: https:/ /doi.org/10.1007/978-81-322-2 262-0_17 (accessed on 2 February 2021). 
67. Akmal, S.; Abul, B. Dysfunctional Horticulture Value Chains and the Need for Modern Marketing Infrastructure: The Case of Viet Nam; Sustainable Development and Climate Change Department: Hanoi, Vietnam, 2019; Available online: https:/ /www.adb.org/ sites/default/files/publication/534726/dysfunctional-horticulture-value-chains-viet-nam.pdf (accessed on 2 February 2021).

68. Tran, N. Năm 2020, Dân Số Trung Bình Đạt 97,3 Triệu Người. In 2020, Vietnam Population Reaches 97.3 Million People; People journal: Hanoi, Vietnam, 2019; Available online: https:/ / nhandan.com.vn/tin-tuc-y-te/nam-2020-dan-so-trung-binh-dat-97-3 -trieu-nguoi-446838 (accessed on 3 December 2020).

69. Chiffoleau, Y.; Dourian, T. Sustainable Food Supply Chains: Is Shortening the Answer? A Literature Review for a Research and Innovation Agenda. Sustainability 2020, 12, 9831. [CrossRef]

70. Galletta, A. Mastering the Semi-Structured Interview and Beyond: From Research Design to Analysis and Publication; New York University Press: New York, NY, USA; London, UK, 2013; p. 45.

71. Converse, J.M.; Presser, S. Survey Questions: Handcrafting the Standardized Questionnaire, 1st ed.; SAGE Publications: London, UK, 1986.

72. Jamshed, S. Qualitative Research Method-Interviewing and Observation. J. Basic Clin. Pharm. 2014, 5, 87-88. [CrossRef]

73. Islam, M.N. An Introduction to Sampling Methods: Theory and Applications, 3rd ed.; Book World: Dhaka, Bangladesh, 2005.

74. Nga, B.T.; Hao, L.T.T.; Hung, B.V.; Van, B.T.; Van, D.H.; Mai, N.N.; Thuy, D.T.N.; Oanh, T.T.K.; Huyen, T.T.T.; Trang, N.T.T. Smallholder Contract Farming in the Short Food Chain of Vietnam: A Case of Arable Farming. East Afr. Sch. J. Econ. Bus. Manag. 2020, 3, 437-445.

75. VOV. VOV: Hanoi, Vietnam. 2020. Available online: Dnrtv.org.vn/tin-tuc-n60690/muc-tieu-tang-so-luong-hop-tac-xa-kinh-tetap-the-khoang-18-vao-nam-2025.html (accessed on 3 December 2020).

76. Alonso, A.D.; O'Neill, M.A. Interest in Maximisation and Value-Added Produce: A Preliminary Study from Chilton County, Alabama. Br. Food J. 2011, 113, 637-655. [CrossRef]

77. Aubry, C.; Chifoleau, Y. Le developpement des circuits courts et l'agriculture périurbaine: Histoire, évolution en cours et questions actuelles. Innov. Agron. 2009, 5, 53-67.

78. Wiskerke, J.S.C. On Places Lost and Places Regained: Reflections on the Alternative Food Geography and Sustainable Regional Development. Int. Plan. Stud. 2009, 14, 369-387. [CrossRef]

79. Allen, P.; FitzSimmons, M.; Goodman, M.; Warner, K. Shifting plates in the agri-food landscape: The tectonics of alternative agri-food initiatives in California. J. Rural Stud. 2003, 19, 61-75. [CrossRef] 